Research article

UDK: $637.07: 579.835 .9$

DOI: $10.2478 /$ acve-2021-0017

\title{
METHOD-RELATED IMPACTS ON CAMPYLOBACTER COLI RECOVERY FROM SAMPLING MATERIALS AND MEAT
}

\author{
Thomai LAZOU ${ }^{1 *}$, Eleni IOSSIFIDOU ${ }^{1}$, Chrysostomos DOVAS ${ }^{2}$ \\ ${ }^{1}$ Laboratory of Hygiene of Foods of Animal Origin - Veterinary Public Health, School of Veterinary \\ Medicine, Faculty of Health Sciences, Aristotle University of Thessaloniki, Thessaloniki, Greece; \\ ${ }^{2}$ Diagnostic Laboratory, School of Veterinary Medicine, Faculty of Health Sciences, Aristotle University \\ of Thessaloniki, Thessaloniki, Greece.
}

(Received 16 March, Accepted 09 June 2021)

A defined Campylobacter coli (C. coli) suspension was inoculated on sterile sampling materials (cotton bud, polyester bud, cellulose sponge) and pieces of lamb meat. Various combinations of diluents (phosphate buffer saline \pm Tween ${ }^{\circledR 80}$ ) and sampling methods (direct homogenization, simulating the excision method for meat, and swabbing) were investigated for the recovery (detachment) of $C$. coli cells from the inoculated samples. The obtained C. coli bacteria, as quantified by real-time PCR with respect to the dilution factors and the initial inoculum, were used for the calculation of the recovery (\%) per sampling material and method. Regarding artificially inoculated sampling materials, the lowest recovery was observed for cotton buds $(2.8 \%)$ and the highest for cellulose sponge $(28.9 \%)$, and the differences between the obtained results were statistically significant $(\mathrm{P}<0.05)$. As regards lamb meat, the lowest recovery was observed for swabbing with cotton buds $(3.2 \%)$ and the highest for direct homogenization $(10.7 \%)$. The results indicate an overall low rate of bacterial recovery from contaminated samples, with cellulose sponges and polyester buds being significantly superior to cotton buds, and direct homogenization of meat with diluent better than swabbing. The type of sampling materials and methods applied for the quantification of C. coli entails a key impact on determining the actual contamination of the examined samples.

Key words: Campylobacter, microbiological sampling, bacterial recovery, lamb meat

\section{INTRODUCTION}

The awareness of the genuine population of foodborne pathogens that could be released and recovered from meat surfaces is necessary for the accurate evaluation of data relevant to veterinary public health. The relative effectiveness of destructive and non-destructive sampling methods has been addressed in several studies that have recognized the type of meat and targeted microbes as influential factors for the recovery of bacterial cells [1-4]. In the case of naturally contaminated carcasses, where

*Corresponding author: e-mail: tlazou@vet.auth.gr 
the real bacterial contamination is unknown, results normally rely on the ratio of colony forming units (CFU) obtained from destructive and non-destructive sampling methods in order to compare the relative bacterial recovery between them. The meat industry favours the use of non-destructive methods, such as swab sampling, since they neither damage the carcass surface nor affect its commercial value in contrast to excision methods $[1,3,5]$. However, recovery of bacteria from swabbing materials is dictated by the specimen uptake into and its subsequent release from the adsorbing material. Both the uptake and release depend on the corresponding capacity, chemical and physical characteristics of the swabbing material [6]. As a consequence, excision typically yields higher counts of bacteria recovered from sampled meat surfaces compared to swab sampling $[1,5,7]$.

There are no available data as yet regarding the relative efficiency of different sampling materials and methods for microbial recovery (detachment of bacterial cells from sampled surfaces) and enumeration of Campylobacter coli (C. coli) from meat samples. Nevertheless, campylobacteriosis remains the most commonly reported foodborne gastroenteritis in the European Union (EU) since 2005 and C. coli has been recognized as the most prevalent Campylobacter species isolated from productive animals and products thereof, including lamb meat, in various Southern EU Member States [815]. The degree of detachment of bacterial pathogens from meat cannot be defined in non-artificially inoculated samples, such as dressed carcasses and meat at retail, since their actual population is unknown. Therefore, the aim of the present study was to investigate the in vitro recovery (detachment) of $C$. coli bacteria from artificially inoculated sampling materials and lamb meat by utilizing different technical approaches.

\section{MATERIALS AND METHODS}

\section{Bacterial inoculum preparation}

The test strain Campylobacter coli ATCC® $43478^{\mathrm{TM}}$ (LGC Standards GmbH) was recovered from storage and purified in selective media according to a previously described preparation protocol [15]. For the generation of a pure C. coli suspension, five overnight and well-isolated colonies on Columbia blood agar (CBA; Oxoid) were inoculated in $200 \mathrm{~mL}$ of Cation-Adjusted Mueller Hinton Broth (CAMHB; BBL ${ }^{\mathrm{TM}}$ $\mathrm{BD})$ and cultivated at $37^{\circ} \mathrm{C}$ for $22 \pm 2$ hours under microaerophilic conditions (GENbox microaer and GENbox jar; BioMérieux). Then, two aliquots of $100 \mu \mathrm{L}$ each (quantification controls) from the pure bacterial suspension (Figure 1 - point A) were subjected to DNA extraction followed by real-time PCR (qPCR) (Figure 1 points $\mathrm{B} \& \mathrm{C}$ ) in order to determine the corresponding average count (cell equivalents $\mathrm{mL}^{-1}$; one genome copy $=$ one cell equivalent) of the initial $C$. coli population $(100$ $\mu \mathrm{L}$ ) from the same pure bacterial suspension that was inoculated on each sampling material and lamb meat sample (Figure 1 - point D). 


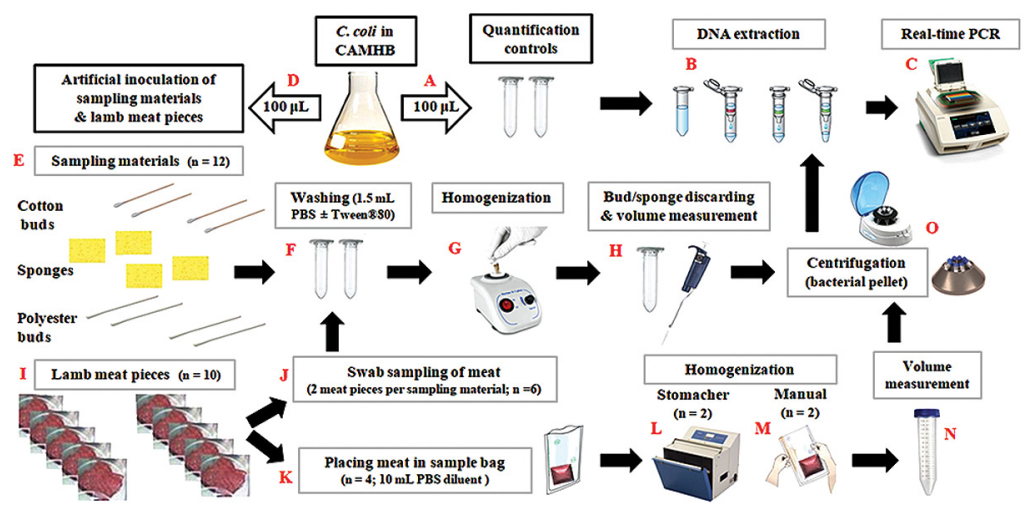

Figure 1. Summarized overview of the applied experimental scheme

\section{Artificial inoculation and processing of sampling materials and lamb meat}

A summarized overview of the applied experimental scheme is illustrated in Figure 1. A volume of $100 \mu \mathrm{L}$ of the pure C. coli suspension in CAMHB was used for the artificial inoculation of each sampling material and lamb meat piece (Figure 1 - point D). The following types of sampling materials were directly inoculated in quadruplicates (Figure 1 - point E): cotton bud (Delta Lab), polyester bud (polyethylene terephthalate, Dacron ${ }^{\circledR}$ ), and cellulose sponge aseptically cut into $10 \mathrm{~mm} \times 3 \mathrm{~mm}$ pieces (WhirlPak ${ }^{\circledR}$ Speci-Sponge ${ }^{\circledR}$, Nasco). Each sponge and tip of the buds (after cracking and discarding the bud rods) was transferred into individual microcentrifuge tubes (2.0 $\mathrm{mL}$, Kisker Biotech GmbH \& Co). Then, one pair (two items) per sampling material was washed and homogenized (vortex) with $1.5 \mathrm{~mL}$ of $10 \mathrm{mM}$ phosphate-buffered saline (PBS; pH 7.0; Sigma-Aldrich) and the other pair with $1.5 \mathrm{~mL}$ of $10 \mathrm{mM}$ PBS supplemented with $0.05 \%$ (w/v) Tween ${ }^{\circledR} 80$ (Sigma-Aldrich), respectively (Figure 1 point F). Following homogenization (Figure 1 - point $G$ ), each sampling material was discarded after being squeezed against the inner wall of the centrifuge tube by utilizing disposable sterile forceps (Sigma-Aldrich) so as to drain the excess of homogenized suspension (Figure 1 - point $\mathrm{H}$ ).

A deboned lamb leg was purchased from the retail market. Once the C. coli-free status was confirmed according to a previously described procedure [16], the meat was sliced aseptically into 10 pieces $\left(5 \times 5 \mathrm{~cm} ; 25 \mathrm{~cm}^{2}\right.$ free surface for inoculation) that were individually placed in sterile petri dishes. No method of decontamination of the autochthonous microbiota on meat was applied. Each meat piece was then inoculated by uniformly applying $100 \mu \mathrm{L}$ of the pure C. coli suspension in CAMHB on its free surface (Figure $1-$ point $\mathrm{D}$ ) and then stored in a refrigerator set at $4^{\circ} \mathrm{C}$ for $24 \pm 1$ hours. Next, six (6) out of the 10 meat pieces were sampled by utilizing non-destructive techniques (Figure 1 - point J). In particular, each one of the three types of sterile sampling materials was used to swab the surface of two meat pieces (3 types of sampling materials $\times 2$ meat pieces $=6$ meat pieces). The sampling materials 
were then subjected to the same washing (Figure 1 - point F) and homogenization (Figure 1 - point G) procedures as described previously but without supplementing PBS with Tween ${ }^{\circledR} 80$. In order to simulate the procedure normally followed for meat samples obtained by the destructive method of excision, the rest four meat samples were placed individually in sterile sample bags (Whirl-Pak ${ }^{\circledR}$ Vertical filter bag, Nasco) and $10 \mathrm{~mL}$ of $10 \mathrm{mM}$ PBS were added per sample (Figure 1 - point K). Next, two (2) of the meat samples were homogenized using a stomacher blender (400 Lab Blender, Seward Medical) (Figure 1 - point L) and the other two (2) manually for two (2) minutes (Figure 1 - point M). In order to obtain the homogenised suspension from each bag, each meat sample was manually squeezed from the outside of the bag while the liquid phase was poured through the bag filter into a conical centrifuge tube (15



In all cases, the volume of the final homogenized suspensions was measured by utilizing a calibrated micropipette (Figure 1 - point $\mathrm{H}$ if $1.5 \mathrm{~mL}$ of diluent was initially used) or conical centrifuge tube (Figure 1 - point $\mathrm{N}$ if $10 \mathrm{~mL}$ of diluent was initially used), and then centrifuged $\left(12,000 \times g\right.$ at $4^{\circ} \mathrm{C}$ for 5 minutes $)$ to harvest the corresponding bacterial pellet (Figure 1 - point $\mathrm{O}$ ).

\section{Extraction of genomic DNA and real-time PCR}

A formerly published protocol [11] was used for the extraction of C. coligenomic DNA (Figure 1 - point B). In brief, the suspension of each quantification control $(100 \mu \mathrm{L})$ (Figure 1 - point A) and each harvested bacterial pellet (Figure 1 - point $\mathrm{O}$ ) was mixed with $100 \mu \mathrm{L}$ of "Lysis buffer I" (50 mM Tris-HCl, $50 \mathrm{mM}$ EDTA, 4 M Guanidinium hydrochloride-GuHCl, $10 \mathrm{mM} \mathrm{CaCl}$, 1\% Triton X-100, and 2\% N-lauroyl-sarcosine, $\mathrm{pH} 7.5$; Merck) and $25 \mu \mathrm{L}$ of proteinase K (0.56 mg; New England Biolabs), and then incubated at $56^{\circ} \mathrm{C}$ for 1 hour. Subsequently, $250 \mu \mathrm{L}$ of "Lysis buffer II" $(50 \mathrm{mM}$ Tris-HCl, $25 \mathrm{mM}$ EDTA, $8 \mathrm{M} \mathrm{GuHCl}, 3 \%$ Triton X-100, and 3\% N-lauroyl-sarcosine, $\mathrm{pH}$ 6.3; Merck) were added followed by incubation at $70^{\circ} \mathrm{C}$ for 10 minutes. Absolute ethanol $(250 \mu \mathrm{L}$; Merck) was added to the lysates, which were then passed through a silica column (FT-2.0; Kisker Biotech GmbH \& Co) by centrifugation $(8,000 \times g)$. Columns were washed three times, once with "Wash buffer I" (25 mM Tris-HCl, $4 \mathrm{M}$ $\mathrm{GuHCl}$, and 50\% ethanol, $\mathrm{pH}$ 6.6; Merck), and twice with "Wash buffer II" (10 mM Tris- $\mathrm{HCl}, 0.1 \mathrm{M} \mathrm{NaCl}$, and 80\% ethanol, $\mathrm{pH}$ 6.6; Merck), followed by elution in 100 $\mu \mathrm{L}$ TE buffer (Applichem).

A previously described real-time PCR (qPCR) assay [16], targeting the serine hydroxymethyltransferase $(g h \mathrm{~A})$ single-copy gene of $C$. coli (one genome copy represents one cell equivalent), was applied for molecular identification and concurrent quantification of the initial inoculums and harvested bacterial pellets. Briefly, the primers Cc-F (5'-TGTAAAACCAAAGCTTATCGTGTGC-3') and Cc-R (5'-AGTCCAGCAATGTGTGCAATG-3') were used, along with the Cc-FAM TaqMan probe (5'-6-FAM-AGCTCCAACTTCATCCGCAATCTCTCT-BHQ1-3'). The $50 \mu \mathrm{L}$ qPCR reaction was comprised by $1 \times$ ThermoPol ${ }^{\circledR}$ DF reaction buffer 
(New England Biolabs), $0.2 \mu \mathrm{M}$ of each primer, $0.4 \mu \mathrm{M}$ of the probe, $0.2 \mathrm{mM}$ of each dNTP, $2.5 \mathrm{mM} \mathrm{MgSO} 4,4 \mathrm{U}$ HotStarTaq DNA polymerase (Qiagen, Hilden, Germany), and $15 \mu \mathrm{L}$ of DNA extract (template). The following cycling conditions were applied: $95^{\circ} \mathrm{C}$ for 15 minutes, followed by 45 cycles in two steps: (i) $95^{\circ} \mathrm{C}$ for 30 seconds and (ii) $60^{\circ} \mathrm{C}$ for 50 seconds. Fluorescence was measured at the end of each cycle.

A standard curve was generated in order to estimate the amplification efficiency and the linearity of the method according to a previously described methodology [16]. In brief, serial 10-fold dilutions of test strain C. coli ATCC ${ }^{\circledR} 43478^{\mathrm{TM}}$ pure DNA $\left(10^{7}-10^{0}\right.$ copies per reaction) were prepared in TE buffer (Applichem) containing $0.04 \mu \mathrm{g} / \mu \mathrm{L}$ carrier RNA (Qiagen) and each of these calibrator dilutions was run in triplicate. In order to determine the limit of detection (LOD), two-fold serial dilutions representing 32 down to one $C$. coli cell equivalents per assay were prepared in TE containing carrier RNA and each dilution was tested in eight independent replicates. The LOD was determined with $95 \%$ probability of detection, by applying probit regression analysis. The repeatability of the developed assay was evaluated by testing 20 C. coli $^{\text {ATCC }}{ }^{\circledR}$ $43478^{\mathrm{TM}}$ genome copies in quintuplicate in three independent runs. The mean $\mathrm{C} t$ (cycle threshold) value, standard deviation (SD) and coefficient of variation (CV) were determined within each run (intra-assay) and between the three runs (inter-assay). The qPCR assay exhibited a linear range of $10^{0}-10^{7}$ copies per reaction $\left(\mathrm{R}^{2}>0.99\right)$, with a PCR efficiency of $93.4 \%$ and an LOD of 7.046 copies per reaction (95\% confidence interval). The standard curve was described by the equation $y=10^{[(41.763-\mathrm{Ct}) / 3.491)]}$, where y represents the genome copies (one genome copy $=$ one cell equivalent) per qPCR reaction. The inter-assay repeatability of $\mathrm{C} t$ values of the three runs (mean $\pm \mathrm{SD}$ ) was $36.99 \pm 0.50,37.5 \pm 0.33$ and $37.47 \pm 0.20$, the intra-assay repeatability was $37.20 \pm$ 0.25 . The inter-assay and intra-assay CV values were $0.90 \%$ and $0.67 \%$, respectively. [16].

\section{C. coli quantification and data analysis}

Microsoft Office Excel 2010 (Microsoft Corporation, Redmond, Washington, U.S.A.) was used for the calculation of $C$. coli cell equivalent counts (mean \pm SD) obtained by each treatment. The recovery (\% detachment of $C$. coli cells from samples) per treatment was calculated by taking into consideration the standard curve of the qPCR reaction, the bacterial pellet count (the cell equivalents in $100 \mu \mathrm{L}$ of DNA extract were calculated based on the result per qPCR assay), the ratio of the volume of the obtained homogenized suspension to the initial volume of diluent used per sample, and the original C. coli inoculum (mean count of the quantification controls).

Statistical analyses were performed using IBM SPSS version 25 (IBM Corp., Armonk, NY). The assumption of normality of variances was assessed using the Shapiro-Wilk and Kolmogorov-Smirnov tests along with P-P and Q-Q plots. Finally, the differences between the $C$. coli cell equivalent counts obtained from each inoculated sampling 
material (cotton bud, sponge, and polyester bud) were statistically analyzed using oneway ANOVA. The Bonferroni post hoc test was applied to allow for adjustment of multiple comparisons. A $\mathrm{P}<0.05$ value was considered statistically significant.

\section{RESULTS}

The overall count (mean $\pm \mathrm{SD}$ ) of the pure $C$. coli suspensions (quantification controls) that were inoculated into the given experimental samples was $\log _{10} 6.38 \pm 0.04 \mathrm{CFU}$, as illustrated in Figure 2. An overall low bacterial recovery $(3.2-28.9 \%)$ from the artificially inoculated samples was determined by qPCR, with cellulose sponge and polyester bud being superior to cotton bud, and direct homogenization of meat more efficient than swabbing (Figure 2).

(A)

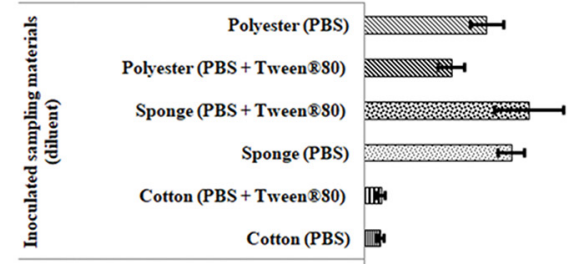

(B)

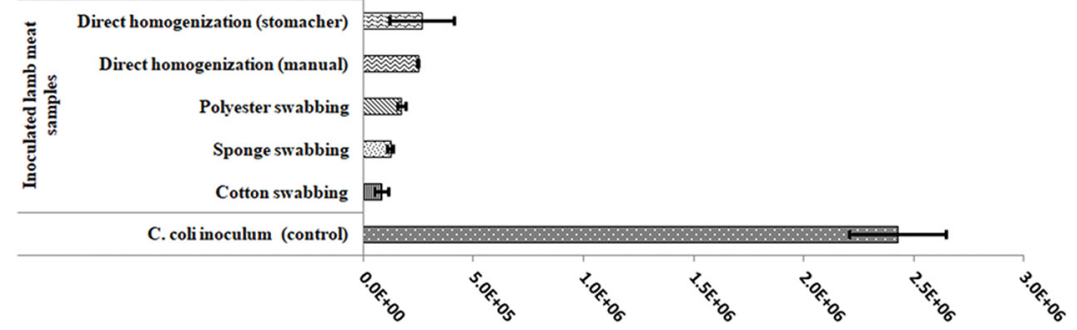

Figure 2. Cell equivalent counts of C. coli initial inoculum and recovered bacteria from (A) inoculated sampling materials and (B) inoculated lamb meat, as determined by qPCR. Each bar represents the mean \pm standard deviation of results from independent repetitions.

Regarding artificially inoculated sampling materials, an ascending overall recovery (\%) was observed for cotton bud, polyester bud and cellulose sponge, respectively (Figure $3 A)$. Supplementing PBS with $0.05 \%$ (w/v) Tween ${ }^{\circledR} 80$ enhanced only slightly the release of $C$. coli from cellulose sponges and cotton buds compared to using the PBS diluent alone. This finding was not observed in the case of polyester buds, where the absence rather than the presence of Tween $\AA 80$ resulted in somewhat higher C. coli recovery (\%). Nevertheless, the observed impact of Tween $₫ 80$ on recovery rates in all cases was rather imperceptible. Therefore, when $C$. coli counts obtained from artificially inoculated sampling materials were grouped per type of adsorbing matrix regardless of the diluent composition, normality of data was detected that allowed further statistical analysis. In particular, cotton buds yielded statistically highly significant $(\mathrm{P}<0.001)$ lower counts compared to the other two types of materials. The 
counts of $C$. coli obtained by cellulose sponges were significantly higher than those by polyester buds $(\mathrm{P}=0.014)$.
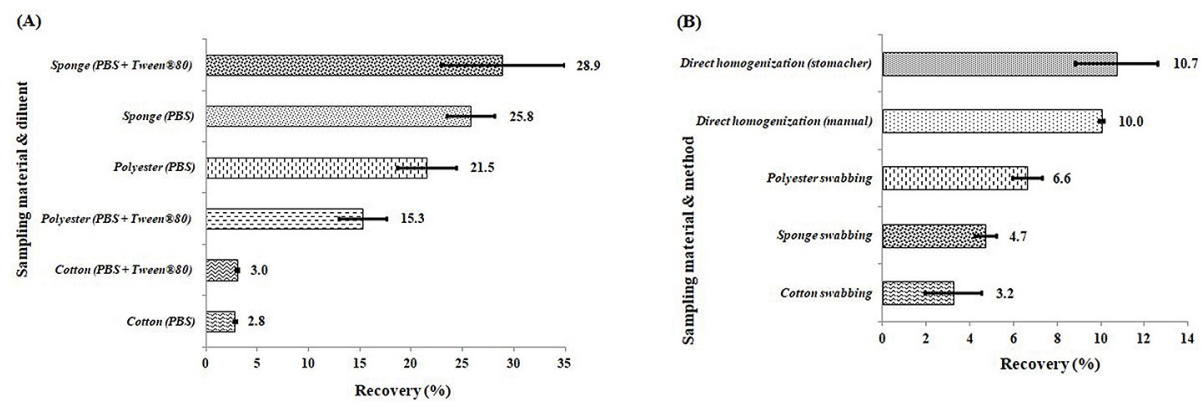

Figure 3. C. coli recovery (\%) from inoculated (A) sampling materials and (B) lamb meat, as determined by qPCR. Each bar represents the mean \pm standard deviation of recovery $(\%)$ results from independent repetitions.

The detachment of campylobacters from the inoculated meat samples via direct homogenization (equivalent to the destructive method of excision) was observed to be higher than utilizing the non-destructive method of swabbing with the lowest recovery (\%) being observed for swabbing with a cotton bud (Figure 3B). The dataset corresponding to the artificially inoculated meat samples could not be further statistically analyzed.

\section{DISCUSSION}

In-house standardization of traditional hygiene sampling techniques has been previously highlighted as a necessity to address deficiencies that could influence the interpretation of microbial contamination results [17]. This study provides an insight on the relative efficiency of ordinary sampling methods for the recovery of $C$. coli from artificially inoculated materials and lamb meat. The aim was to investigate different sampling schemes in terms of their efficacy to detach C. coli cells from inoculated samples regardless of the viability state of bacteria.

The recovery (detachment) of bacteria from swabbing materials is dictated by the specimen uptake into the adsorbing material during sampling and its subsequent release from the swab during its homogenization with the diluent [6]. Likewise, the direct recovery of bacteria from meat (e.g. samples that have been excised from carcasses at the abattoir or meat at retail) depends on how loosely or tightly the bacterial cells are attached to the meat surface, thus, resulting in high or low release, respectively, during the direct homogenization of meat with the diluent $[2,4,5]$. As a result, the true bacterial recovery rate depends on the type of tested sample (e.g. organic or inorganic material, food matrix), sampling method (destructive or non-destructive), sampling materials (physicochemical composition of adsorbing materials and diluents) and targeted 
microbial species [1-7]. After sampling and during sample analysis in the laboratory, any given quantification method (molecular or classical) will be applied on the same generated homogenized suspension for the enumeration of the targeted microbial species. Evidently, different quantification methods will generate different results due to the inherent capabilities and shortcomings of each method [18]. In the case of meat, all enumeration methods are applied on bacteria that are already detached from the samples and are present in the homogenized suspension (their recovery is already predefined at this point). Moreover, the degree of detachment of bacterial pathogens, such as $C$. coli, from randomly contaminated meat, such as dressed carcasses and meat at retail, cannot be calculated since their actual number on meat is unknown. Only an unknown fraction of this unknown population is actually obtained by sampling and then enumerated. Therefore, in the present study, the artificial inoculation of samples with a defined $C$. coli population and the inclusion of quantification controls (original inoculum) have enabled a direct calculation of the recovery (\%) of campylobacters in each sampling scheme.

The use of qPCR provided a subjective evaluation of the total detachment of C. coli cells from samples, which were quantified as genome copies corresponding to cell equivalents, regardless of the viability of the recovered campylobacters; culturable, viable but nonculturable (VBNC) as well as dead C. coli bacteria were concurrently quantified in this study. Lower counts and recovery rates would be expected if culturebased methods were used instead, since only culturable $C$. coli bacteria would form colonies on agar plates in this case, in contrast to stressed, injured and/or dead cells [18]. More specifically, classical colony counting cannot detect VBNC C. coli cells, which are quickly generated under stressful environmental conditions (e.g. low temperatures and atmospheric oxygen) and are potentially infectious and equally important for public health [18,19]. Interestingly, colony-counting on mCCDA (modified Charcoal Cefoperazone Deoxycholate agar), which is the mandatory solid selective medium of choice according to the standard colony-count technique for enumeration of Campylobacter [20], has been reported to underestimate even the culturable $C$. coli cells due to the selective factors that impose an additional hurdle to the already stressed bacteria present on meat under refrigeration and atmospheric oxygen [18]. This selective medium should have been used if a standard microbiological method would be included in the present study, since no method of decontamination of the autochthonous microbiota on meat was applied. Therefore, no classical microbiological method utilizing mCCDA was included in the study design in order to avoid the introduction of bias during the interpretation of total $C$. coli recovery $(\%)$ results. Even so, the results obtained by absolute quantification (qPCR) in the present study, indicated an overall low $C$. coli recovery from the artificially inoculated sampling materials and meat samples. The fact that only one test strain of $C$. coli was used in the present study is, however, a recognised limitation regarding the overall recovery from different surfaces and, therefore, more studies utilizing various strains of this pathogen are needed to provide better perspective on this matter. 
The ascending recovery (\%) that was observed in the current study for cotton buds, polyester buds and cellulose sponges, respectively, are in compliance with previously reported data. In particular, cellulose sponge has been reported to exhibit the highest bacterial release and cotton bud the lowest as regards the recovery of the foodborne pathogens Salmonella, Staphylococcus aureus, Escherichia coli and Listeria monocytogenes from food contact surfaces [21]. The formerly reported high bacteria-retaining ability of cotton buds resulting in bacteria remaining trapped within its threads could justify its low efficiency of bacterial release [17]. With the aim to increase the efficiency

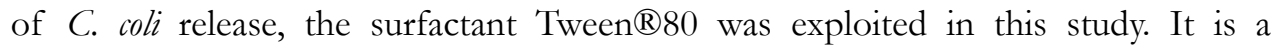
polyethylene sorbitol ester, which, according to the specifications, has been widely used in biochemical applications including emulsifying and dispersing substances in food products without exhibiting any activity as an anti-bacterial agent. The presence of Tween ${ }^{\circledR} 80$ within a moisturising diluent has been reported to likely reduce the surface tension of the liquid and may reduce the mechanical pressure generated by the swabbing activities, hence, minimizing bacterial injury [17]. Indeed, supplementing PBS with $0.05 \%(\mathrm{w} / \mathrm{v})$ Tween ${ }^{\circledR} 80$ enhanced at some point the release of $C$. coli from the cellulose sponges and cotton buds compared to using the PBS diluent alone in the current study. However, this finding was not observed in the case of the polyester bud, where the absence rather than the presence of Tween $₫ 80$ resulted in marginally higher $C$. coli recovery (\%). Overall, the results of the present study indicate a rather imperceptible impact of Tween $₫ 80$ on $C$. coli recovery rates from sampling materials. More data are needed in order to reveal any chemical interaction between the polyester bud and polyethylene sorbitol ester and/or diverse Campylobacter strains. In any case, the addition of Tween $® 80$ to the elusion buffer could be considered for bacterial release from sampling materials due to its dispersing ability and the absence of antibacterial activity.

The observed overall low release of $C$. coli bacterial cells from the artificially inoculated lamb meat samples could, at least partly, be explained by a tight association of the bacterial cells to the meat surface. Differences in the recovery of loosely and tightly associated bacteria on carcass surface have been previously reported between swabbing, stomaching and grinding, with only the latter method being able to release the tightly associated bacterial cells $[1,4]$. The irreversible attachment of bacteria and biofilm formation has been reported to take place 30 minutes to a few hours after dressing of carcasses $[1,22]$. In the present study, meat samples after inoculation were stored for almost a whole day before sampling so as to simulate the post-chilling stages of contaminated lamb meat in the food chain from the abattoir to the retail market. This period was sufficient for $C$. coli to adjust and adhere to the surface, thus, rendering the release of bacteria from meat as realistic as possible. Moreover, an already recognised limitation of swabbing is the inherent double bacterial transfer, from meat to swab and from swab to diluent during washing, each one with a corresponding recovery rate that contributes to a low total recovery [23]. This fact could elucidate the observed in the present study superiority of direct homogenization of meat samples to swabbing 
of meat surfaces in terms of bacterial release. In terms of bacterial recovery from naturally contaminated carcasses and the relative ratio of the obtained CFU by different methods, similar findings highlighting the superiority of destructive over nondestructive sampling methods have been reported previously [5,7]. Excision sampling of meat followed by direct homogenization with a diluent is considered more accurate and a method of choice for Camplyloabacter detection and enumeration on poultry carcasses $[15,20]$, though it is less practical than swab sampling. As yet, no univocal conversion factor between the results obtained by these two sampling methods has been established $[1,5]$. Consequently, the obtained results of microbial recovery during sampling should be interpreted with respect to the relative capacities of the method applied and within the in-house performance capabilities of each laboratory.

\section{CONCLUSIONS}

The selection of materials and methods for the recovery of bacterial pathogens is known to have a remarkable impact on evaluating the actual contamination of both the examined meat samples and the pertaining veterinary public health implications. The results of the present study could assist the approach of selecting the most suitable combination of common sampling materials and methods to acquire $C$. coli from meat samples. The release of campylobacters, as well as other bacteria from contaminated samples, cannot be absolute, though excision followed by direct homogenization seems to be the best sampling method in terms of accuracy. However, when swab sampling is selected over excision for practical reasons, the utilization of a cellulose sponge and a diluent supplemented with a surfactant, such as Tween ${ }^{\circledR} 80$, could be a useful sampling scheme for a relatively optimized recovery of campylobacters. Further studies utilizing combinations of swab materials and diluents as well as various Campylobacter strains are deemed necessary in order to append more data to the findings of this study.

\section{Acknowledgements}

This research received no specific grant from any funding agency in the public, commercial, or not-for-profit sectors.

\section{Authors' contributions}

TL participated in the design of the study, performed the laboratory experiments and the statistical analysis, and drafted the manuscript. EI participated in the design of the study and helped to draft the manuscript. CD conceived of the study, and participated in its design and coordination and helped to draft the manuscript. All authors read and approved the final manuscript. 


\section{Declaration of conflicting interests}

The author(s) declared no potential conflicts of interest with respect to the research, authorship, and/or publication of this article.

\section{REFERENCES}

1. Capita R, Prieto M, Alonso-Calleja C: Sampling methods for microbiological analysis of red meat and poultry carcasses. J Food Protect 2004, 67(6):1303-1308.

2. Martinez B, Celda MF, Anastasio B, Garcia I, Lopez-Mendoza MC: Microbiological sampling of carcasses by excision or swabbing with three types of sponge or gauze. J Food Protect 2010, 73:81-87.

3. Milios KT, Drosinos EH, Zoiopoulos PE: Food Safety Management System validation and verification in meat industry: Carcass sampling methods for microbiological hygiene criteria - A review. Food Control 2014, 43:74-81.

4. Singh PH, Lee C, Chin KB, Ha SD, Kang I: Quantification of loosely associated and tightly associated bacteria on broiler carcass skin using swabbing, stomaching, and grinding methods. Poultry Sci 2015, 94(12):3034-3039.

5. Gallina S, Bianchi DM, Ru G, Maurella C, Barzanti P, Baioni E, Virgilio S, Mioni R, Lanni L, Migliazzo A, Losio MN, Bove D, Scuota S, Goffredo E, Decastelli L: Microbiological recovery from bovine, swine, equine, and ovine carcasses: Comparison of excision, sponge and swab sampling methods. Food Control 2015, 50:919-924.

6. Warnke P, Warning L, Podbielski A: Some are more equal - a comparative study on swab uptake and release of bacterial suspensions. PLoS One 2014, 9:e102215.

7. Ghafir Y, Daube G: Comparison of swabbing and destructive methods for microbiological pig carcass sampling. Let Appl Microbiol 2008, 47:322-326.

8. Marinou I, Bersimis S, Ioannidis A, Nicolaou C, Mitroussia-Ziouva A, Legakis NJ: Identification and antimicrobial resistance of Campylobacter species isolated from animal sources. Front Microbiol 2012, 3(58):1-6.

9. Nobile CGA, Costantino R, Bianco A, Pileggi C, Pavia M: Prevalence and pattern of antibiotic resistance of Campylobacter spp. in poultry meat in Southern Italy. Food Control 2013, 32:715-718.

10. Lazou T, Houf K, Soultos N, Dovas C, Iossifidou E: Campylobacter in small ruminants at slaughter: prevalence, pulsotypes and antibiotic resistance. Int J Food Microbiol 2014, 173: 54-61.

11. Lazou T, Dovas C, Houf K, Soultos N, Iossifidou E: Diversity of Campylobacter in retail meat and liver of lambs and goat kids. Foodborne Pathog Dis 2014, 11(4):320-328.

12. Torralbo A, Borge C, García-Bocanegra I, Méric G, Perea A, Carbonero A: Higher resistance of Campylobacter coli compared to Campylobacter jejuni at chicken slaughterhouse. Comp Immunol Microbiol Infect Dis 2015, 39:47-52.

13. Pedonese F, Nuvoloni R, Turchi B, Torracca B, Di Giannatale E, Marotta F, Cerri D: Prevalence, phenotypic and genetic diversity of Campylobacter in poultry fresh meat and poultry products on retail sale in Tuscany (Italy). Vet Ital 2017, 53(1):29-37. 
14. EFSA and ECDC (European Food Safety Authority and European Centre for Disease Prevention and Control): The European Union One Health 2019 Zoonoses Report. EFSA J 2021;19(2):6406, 286 pp.

15. Sakaridis I, Papadopoulos T, Boukouvala E, Ekateriniadou L, Samouris G, Zdragas A: Prevalence, Antimicrobial Resistance, and Molecular Typing of Thermophilic Campylobacter Spp. in a Greek Poultry Slaughterhouse. Acta Veterinaria - Beograd 2019, 69(3): 325-339.

16. Lazou TP, Iossifidou EG, Gelasakis AI, Chaintoutis SC, Dovas CI: Viability quantitative PCR utilizing propidium monoazide, spheroplast formation, and Campylobacter coli as a bacterial model. Appl Environ Microbiol 2019, 85:e01499-19.

17. Moore G, Griffith C: Problem associated with traditional hygiene swabbing: The need for in-house standardization. J Appl Microbiol 2007, 103: 1090e1103.

18. Lazou TP, Gelasakis AI, Chaintoutis SC, Iossifidou EG, Dovas CI: Method-Dependent Implications in Foodborne Pathogen Quantification: The Case of Campylobacter coli Survival on Meat as Comparatively Assessed by Colony Count and Viability PCR. Front Microbiol 2021, 12:604933.

19. Zeng D, Chen Z, Jiang Y, Xue F, Li B: Advances and Challenges in Viability Detection of Foodborne Pathogens. Front Microbiol 2016, 7:1833.

20. ISO 10272-2:2017. Microbiology of the food chain-horizontal method for detection and enumeration of Campylobacter spp. - Part 2: colony-count technique.

21. Keeratipibul S, Laovittayanurak T, Pornruangsarp O, Chaturongkasumrit Y, Takahashi H, Techaruvichit P: Effect of swabbing techniques on the efficiency of bacterial recovery from food contact surfaces. Food Control 2017, 77:139-144.

22. Butler JL, Stewart JC, Vanderzant C, Carpenter ZL, Smith GC: Attachment of microorganisms to pork skin and surfaces of beef and lamb carcasses. J Food Protect 1979, 42:401-406.

23. Pepperell R, Reid CA, Solano SN, Hutchison ML, Walters LD, Johnston AM, Buncic S: Experimental comparison of excision and swabbing microbiological sampling methods for carcasses. J Food Protect 2005, 68(10):2163-2168.

\title{
UTICAJ METODE UZORKOVANJA NA DETEKCIJU CAMPYLOBACTER COLI IZ PRIBORA ZA UZORKOVANJE I MESA
}

\author{
Thomai LAZOU, Eleni IOSSIFIDOU, Chrysostomos DOVAS
}

Prethodno određena suspenzija Campylobacter coli inokulisana je na sterilne materijale za uzorkovanje (pamučni štapić, poliesterski štapić, celulozni sunđer) i komade jagnjećeg mesa. Različite kombinacije razređivača (fiziološki rastvor fosfatnog pufera \pm Tveen ${ }^{\circledR} 80$ ) i metode uzimanja uzoraka (direktna homogenizacija, simuliranje metode ekscizije mesa i uzimanje brisa) ispitivane su na uspešnost detekcije ćelija $C$. coli iz inokulisanih uzoraka. Kvantifikacija je urađena PCR-om u realnom vremenu u odnosu 
na faktore razblaženja i početni inokulum i izračunat je nivo detekcije C. coli (\%) prema materijalu i metodi uzimanja uzoraka. Iz veštački inokulisanih materijala za uzimanje uzoraka najniža detekcija ovih bakterija je zabeležena kod pamučnih štapića (2,8\%), a najveća kod celuloznih sunđera $(28,9 \%)$ i utvrdjena je statistički značajna razlika (P $<0,05)$. Kod uzoraka mesa jagnjadi najniža detekcija C. coli zabeležena je iz briseva uzetih pamučnim štapićima (3,2\%), a najveća kod direktne homogenizacije (10,7\%). Dobijeni rezultati ukazuju na generalno slabu stopu detekcije bakterija iz kontaminiranih uzoraka, pri čemu su celulozni sunđeri i poliesterski štapići relativno bolji od pamučnih štapića, a direktna homogenizacija mesa elucionim puferom bolja od uzimanja brisa. Vrsta materijala za uzorkovanje i metode koje se primenjuju za kvantifikaciju C. coli imaju ključni uticaj na utvrđivanje kontaminacije ispitivanih uzoraka ovim bakterijama. 